\title{
Influence of platinum ions \\ on the germination and seedling root growth of different plant species
}

\author{
Anna Kołton ${ }^{1}$, Monika Czaja ${ }^{2}$ \\ ${ }^{1}$ University of Agriculture in Krakow, Faculty of Biotechnology and Horticulture, Institute of Plant Biology \\ and Biotechnology, al.29 Listopada 54,Krakow, Poland; e-mail: koltona@ogr.ur.krakow.pl \\ ${ }^{2}$ University of Agriculture in Krakow, Faculty of Biotechnology and Horticulture, Department of Dendrology \\ and Landscape Architecture, al. 29 Listopada 54,Krakow, Poland; e-mail: mon.czaja@gmail.com
}

(C) 2014 Authors. This is an open access publication, which can be used, distributed and reproduced in any medium according to the Creative Commons CC-BY 4.0 License requiring that the original work has been properly cited.

Received: 30 November 2014; accepted: 27 January 2015

\begin{abstract}
For several decades an increase of platinum in the environment was recorded. This is connected with the release of platinum from automobile catalytic converters and pharmaceutical industries. In the conducted experiments the effect of various forms and concentrations of platinum on the germination and roots growth of different plants (oat, garden cress and tomato) was investigated. Two separate experiments were performed with lower (experiment $1^{\text {st: }}: 1,5$ and $10 \mathrm{mg} / \mathrm{L}$ ) and higher (experiment $2^{\text {nd: }}: 10,20$ and $\left.40 \mathrm{mg} / \mathrm{L}\right)\left[\mathrm{Pt}\left(\mathrm{NH}_{3}\right)_{4}\right]\left(\mathrm{NO}_{3}\right)_{2}$ or $\mathrm{PtCl}_{4}$ dosages.

There was no significant effect of dose and form of platinum on the germination of seeds (experiment $1^{\text {st }}$ and $2^{\text {nd }}$ ). The effect of platinum containing substances dose on root growth of young seedlings was observed during experiment, dependent on the species of tested plants.

The root length of oat plants was similar in all treatments in experiment $1^{\text {st }}$. The shortest tomato roots were observed in the case of a $10 \mathrm{mg} / \mathrm{L}$ of $\mathrm{PtCl}_{4}$, it was statistically shorter than the control plants (treated with water) as well. The roots of the tomato treated with $\left[\mathrm{Pt}\left(\mathrm{NH}_{3}\right)_{4}\right]\left(\mathrm{NO}_{3}\right)_{2}$ were the same length as observed for the control sample. The garden cress root growth was not affected by $\left[\mathrm{Pt}\left(\mathrm{NH}_{3}\right)_{4}\right]\left(\mathrm{NO}_{3}\right)_{2}$, but a solution containing $\mathrm{Pt}^{4+}$ stimulated the root growth.

The roots of tomato and oat treated with $\left[\mathrm{Pt}\left(\mathrm{NH}_{3}\right)_{4}\right]\left(\mathrm{NO}_{3}\right)_{2}$ had similar length as the control plants in contrast to the far shorter roots treated with $\mathrm{PtCl}_{4}$ (experiment $2^{\text {nd }}$ ). Moreover, the treatment with $\left[\mathrm{Pt}\left(\mathrm{NH}_{3}\right)_{4}\right]\left(\mathrm{NO}_{3}\right)_{2}$ stimulated the growth of garden cress roots compared to the control, while only the lowest dose of $\mathrm{PtCl}_{4}$ stimulated the root growth.
\end{abstract}

Keywords: platinum, root growth, tomato, oat, garden cress

\section{INTRODUCTION}

In the urban areas car engines are one of the major sources of environmental pollution. The main contaminants from this source are carbon monoxide $(\mathrm{CO})$, hydrocarbons and nitrogen oxides $\left(\mathrm{NO}_{\mathrm{x}}\right)$, but also products of car parts abrasion (Moldovan et al. 2002). According to European standards, pollution emitted by cars should be limited. New automobile catalytic converters containing Platinum Group Elements (PGEs) such as Pt, Pd and $\mathrm{Rh}$ were introduced. Metals from this group are released to the environment due to everyday car usage. This causes a necessity to study if and how those elements affect living organisms (Palacios et al. 2000). In the recent years, significant increase of platinum is observed in soil, surface water, street dust and plant samples. The PGEs are present in 
the environment mostly due to car usage, but also as a result of jewelry and pharmaceutical industry. Platinum is bioavailable mainly as chloro- or organic complexes, and its most common ionic forms exist in +2 and +4 oxidation states (Pawlak et al. 2014). Plants have the ability to accumulate PGEs in their tissues what was demonstrated in studies conducted on different plant species such as spinach (Spinacia oleracea L.), phacelia (Phacelia tanacetifolia), annual ryegrass (Lolium multiforum), moss (Rhytidiadelphus squarrosus), mushrooms (Vascellum pratense) and others. Dicotyledons (for example tomato, flowering plants which usually have in seed two embryonic leaves) are thought to accumulate more metals than monocotyledons (for example oat - has one embryonic leaf). Platinum is accumulated mostly in the roots and after its translocation to the aboveground parts the toxic symptoms are visible (Ravindra et al. 2004). The concentration of PGEs in the soil and plants located at high-traffic roads was investigated (Djingova et al. 2003, Whiteley \&Murray 2003, Leśniewska et al. 2004a, Dubiella-Jackowska et al. 2007). However, the impact of PGEs on plant growth and development is not a popular topic of research. Heavy metals accumulation in the soil, water and air environment can cause abiotic stress. Such stress disrupts plant growth, especially biomass production and seed yield. Every metal interacts in a different, specific way, depending on soil type, metal form and other ions presence (Ghani 2010). It is confirmed that heavy metals when applied in high doses, decrease seed germination rates as well as root and shoot growth. However the addition of $\mathrm{Zn}$ to alfalfa growing solution even in high doses (40 ppm) increased both root and shoot growth (Aydinalp \& Marinova 2009). Heavy metals are reported to cause delay in germination, reduce the germination percent, inhibit root elongation, seedling development and also affect the seed morphology and physiology (Sethy \& Ghosh 2013). It is known that platinum affect the growth of plants and also inhibition of root growth was reported (Farago et al. 1979, Mikulaskova et al. 2013). In the case of Lemna minor the growth inhibition expressed as reduction in numbers of leaves or total amount of biomass was noted (Supalkova et al. 2008). Some authors also reported the chlorosis of young tissues and dry weight reduction as an effect of platinum on horticultural crops (Pallas \& Jones 1978). The platinum content in road dust collected in the area of Białystok (Poland) ranged from 34.2-110.9 ng/g (Leśniewska et al. 2004a). The platinum content in the soil depends on many factors, including the traffic intensity and the distance from the road, and it may range from 3.8 to as much as $444 \mathrm{ng} / \mathrm{g}$ (Sobrova et al. 2012). The listed values were determined for other countries than Poland. An information that near Poznań (Poland) concentration of platinum may range $0.1-2.7 \mu \mathrm{g} / \mathrm{kg}$ of soil can also be found (Hofman \& Wachowski 2010).

The aim of the presented study was to compare different doses of $\left[\mathrm{Pt}\left(\mathrm{NH}_{3}\right)_{4}\right]\left(\mathrm{NO}_{3}\right)_{2}$ or $\mathrm{PtCl}_{4}$ on the germination and root growth of different plant species. For the experiment three plant species were selected (oat, garden cress and tomato) belonging to monocotyledon and dicotyledons popular in toxicity testing.

\section{MATERIALS AND METHODS}

The effect of different forms and concentrations of platinum on germination and seedling root growth was conducted in two experiments. In both experiments, salts containing platinum at different oxidation state were used: $\mathrm{Pt}^{2+}\left(\left[\mathrm{Pt}\left(\mathrm{NH}_{3}\right)_{4}\right]\left(\mathrm{NO}_{3}\right)_{2}\right)$ and $\mathrm{Pt}^{4+}\left(\mathrm{PtCl}_{4}\right)$. In the first experiment (E1) doses: 1,5 and $10 \mathrm{mg} / \mathrm{L}$ were applied. In the second experiment (E2) concentrations: 10, 20 and $40 \mathrm{mg} / \mathrm{L}$ were used. Both experiments were performed in two separate series. In addition, each serie included control treatment with distilled water. In each experiment there were seven treatments (including control) (Tabs 1,2). Filter paper was placed in Petri dishes and soaked with $3 \mathrm{ml}$ of a suitable solution. For each solution five dishes were prepared, in every dish 20 seeds were sown. In each experiment three plants: oat (Avena sativa), garden cress (Lepidium sativum) and tomato (Lycopersicon esculentum) were used. The dishes were kept in an incubator at $22^{\circ} \mathrm{C}$ in the dark, sealed to reduce evaporation. After 2 days (in the case of oat and cress) or 3 days (in the case of tomato) the evaluation of seed germination and root length measurements were done. The percentage of germinated seeds was calculated. The sown seeds (20) were assumed as $100 \%$ and the number of germinated seeds was $\mathrm{x} \%$. The results were statistically 
analyzed using ANOVA and Fisher LSD test at a given level of significance $\alpha=0.05$ using STATISTICA10 (StatSoft).

Table 1

The content of platinum in solution

\begin{tabular}{|c|c|c|}
\hline $\begin{array}{c}\text { Concentration } \\
\text { of the compound } \\
{\left[\mathbf{P t}\left(\mathrm{NH}_{3}\right)_{4}\right]} \\
\left(\mathrm{NO}_{3}\right)_{2} \text { or } \mathbf{P t C l}_{4} \\
{[\mathbf{m g} / \mathbf{L}]}\end{array}$ & $\begin{array}{c}\text { Concentration } \\
\text { of platinum } \mathbf{P t}^{2+} \\
{[\mathbf{m g} / \mathbf{L}] \text { from }} \\
{\left[\mathbf{P t}\left(\mathrm{NH}_{3}\right)_{4}\right]} \\
\left(\mathrm{NO}_{3}\right)_{2}\end{array}$ & $\begin{array}{c}\text { Concentration } \\
\text { of platinum } \mathbf{P t}^{4+} \\
{[\mathbf{m g} / \mathbf{L}]} \\
\text { from } \\
\mathbf{P t C}_{4} \mathbf{4}\end{array}$ \\
\hline 1 & 0.50 & 0.58 \\
\hline 5 & 2.52 & 2.89 \\
\hline 10 & 5.04 & 5.79 \\
\hline 20 & 10.08 & 11.58 \\
\hline 40 & 20.15 & 23.16 \\
\hline
\end{tabular}

\section{RESULTS}

Two separate experiments were performed. Seeds germination test was conducted. In both experiments there was no significant effect of dose and form of platinum on the germination of tomato and garden cress seeds (Tabs 3,4). Only during the first experiment in the case of oat, a dose of $1 \mathrm{mg} / \mathrm{L}$ of $\mathrm{PtCl}_{4}$ stimulated the germination of seeds. Except this case, generally platinum $\left(\left[\mathrm{Pt}\left(\mathrm{NH}_{3}\right)_{4}\right]\right.$ $\left(\mathrm{NO}_{3}\right)_{2}$ or $\left.\mathrm{PtCl}_{4}\right)$ did not change the percentage of germinated oat seeds in comparison to control samples.

Root growth of young seedling was affected by platinum ions form and concentration. The shortest root of tomato was observed in the case of $10 \mathrm{mg} / \mathrm{L}$ of $\mathrm{PtCl}_{4}$ during the first experiment (Fig. 1).

Table 2

The scheme of experiments

\begin{tabular}{|c|c|c|c|}
\hline Treatment & Compound & \begin{tabular}{c} 
The $\mathbf{1}^{\text {st }} \begin{array}{c}\text { experiment concentration } \\
\text { of the compound } \\
{[\mathbf{m g} / \mathbf{L}]}\end{array}$ \\
\hline 1
\end{tabular}$\quad-\begin{array}{c}\text { The } \mathbf{2}^{\text {nd }} \text { experiment concentration } \\
\text { of the compound } \\
{[\mathbf{m g} / \mathbf{L}]}\end{array}$ \\
\hline 2 & {$\left[\mathrm{Ht}\left(\mathrm{NH}_{3}\right)_{4}\right]\left(\mathrm{NO}_{3}\right)_{2}$} & 1 & - \\
\hline 3 & {$\left[\mathrm{Pt}\left(\mathrm{NH}_{3}\right)_{4}\right]\left(\mathrm{NO}_{3}\right)_{2}$} & 5 & 20 \\
\hline 4 & {$\left[\mathrm{Pt}\left(\mathrm{NH}_{3}\right)_{4}\right]\left(\mathrm{NO}_{3}\right)_{2}$} & 10 & 40 \\
\hline 5 & $\mathrm{PtCl}_{4}$ & 1 & 10 \\
\hline 6 & $\mathrm{PtCl}_{4}$ & 5 & 20 \\
\hline 7 & $\mathrm{PtCl}_{4}$ & 10 & 40 \\
\hline
\end{tabular}

Table 3

Seeds germination of three species influenced by platinum ions - experiment 1

\begin{tabular}{|c|c|c|c|}
\hline \multirow{2}{*}{$\begin{array}{c}\text { Treatment } \\
\text { No. }(\text { dose/form })\end{array}$} & \multicolumn{3}{|c|}{ Germination [\%] } \\
\hline & $\begin{array}{l}\text { Lycopersicon } \\
\text { esculentum }\end{array}$ & Avena sativa & Lepidium sativum \\
\hline 1 (control / $\left.\mathrm{H}_{2} \mathrm{O}\right)$ & 74.5 & $70.0 \mathrm{a}^{*}$ & 96.0 \\
\hline $2\left(1 \mathrm{mg} / \mathrm{L} /\left[\mathrm{Pt}\left(\mathrm{NH}_{3}\right)_{4}\right]\left(\mathrm{NO}_{3}\right)_{2}\right)$ & 75.9 & $77.5 \mathrm{ab}$ & 96.0 \\
\hline $3\left(5 \mathrm{mg} / \mathrm{L} /\left[\mathrm{Pt}\left(\mathrm{NH}_{3}\right)_{4}\right]\left(\mathrm{NO}_{3}\right)_{2}\right)$ & 61.6 & $78.5 \mathrm{ab}$ & 95.0 \\
\hline $4\left(10 \mathrm{mg} / \mathrm{L} /\left[\mathrm{Pt}\left(\mathrm{NH}_{3}\right)_{4}\right]\left(\mathrm{NO}_{3}\right)_{2}\right)$ & 67.1 & $74.0 \mathrm{ab}$ & 99.5 \\
\hline $5\left(1 \mathrm{mg} / \mathrm{L} / \mathrm{PtCl}_{4}\right)$ & 72.5 & $82.5 \mathrm{~b}$ & 98.0 \\
\hline $6\left(5 \mathrm{mg} / \mathrm{L} / \mathrm{PtCl}_{4}\right)$ & 65.3 & $70.0 \mathrm{a}$ & 97.0 \\
\hline $7\left(10 \mathrm{mg} / \mathrm{L} / \mathrm{PtCl}_{4}\right)$ & 65.4 & $78.5 \mathrm{ab}$ & 97.5 \\
\hline Deviation of results & n.s. ${ }^{* *}$ & $P=0.0487$ & n.s. \\
\hline
\end{tabular}

* letters indicate homogenous groups separated with $\alpha=0.05$,

** n.s. - not significant differences between groups. 
Table 4

Seeds germination of three species influenced by platinum ions - experiment 2

\begin{tabular}{|c|c|c|c|}
\hline \multirow{2}{*}{$\begin{array}{c}\text { Treatment } \\
\text { No. (dose/form) }\end{array}$} & \multicolumn{3}{|c|}{ Germination [\%] } \\
\hline & $\begin{array}{l}\text { Lycopersicon } \\
\text { esculentum }\end{array}$ & Avena sativa & Lepidium sativum \\
\hline 1 (control / $\left.\mathrm{H}_{2} \mathrm{O}\right)$ & 82.5 & 43.5 & 95.6 \\
\hline $2\left(10 \mathrm{mg} / \mathrm{L} /\left[\mathrm{Pt}\left(\mathrm{NH}_{3}\right)_{4}\right]\left(\mathrm{NO}_{3}\right)_{2}\right)$ & 87.5 & 53.5 & 98.5 \\
\hline $3\left(20 \mathrm{mg} / \mathrm{L} /\left[\mathrm{Pt}\left(\mathrm{NH}_{3}\right)_{4}\right]\left(\mathrm{NO}_{3}\right)_{2}\right)$ & 90.0 & 62.5 & 97.4 \\
\hline $4\left(40 \mathrm{mg} / \mathrm{L} /\left[\mathrm{Pt}\left(\mathrm{NH}_{3}\right)_{4}\right]\left(\mathrm{NO}_{3}\right)_{2}{ }^{2}\right)$ & 87.2 & 60.5 & 99.5 \\
\hline $5\left(10 \mathrm{mg} / \mathrm{L} / \mathrm{PtCl}_{4}\right)$ & 89.0 & 53.0 & 97.0 \\
\hline $6\left(20 \mathrm{mg} / \mathrm{L} / \mathrm{PtCl}_{4}\right)$ & 95.0 & 53.0 & 95.5 \\
\hline $7\left(40 \mathrm{mg} / \mathrm{L} / \mathrm{PtCl}_{4}\right)$ & 84.3 & 47.5 & 95.0 \\
\hline Deviation of results & n.s.* & n.s. & n.s. \\
\hline
\end{tabular}

${ }^{\star}$ n.s. - not significant differences between groups

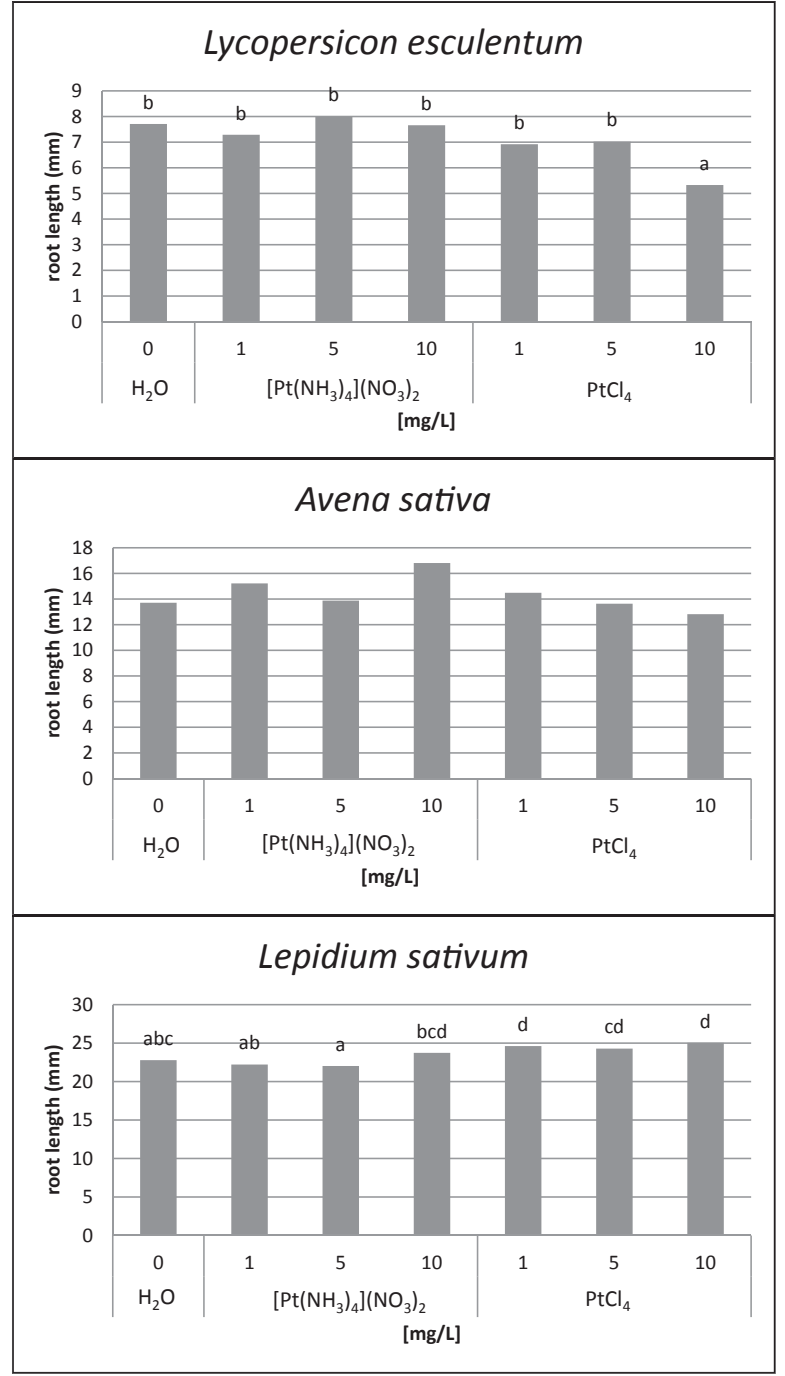

Fig. 1. Root length $(\mathrm{mm})$ of the three plant species affected by platinum ions - experiment $1^{\text {st }}$. Letters indicate homogenous groups separated with $\alpha=0.05$, lack of letters indicate lack of significant differences

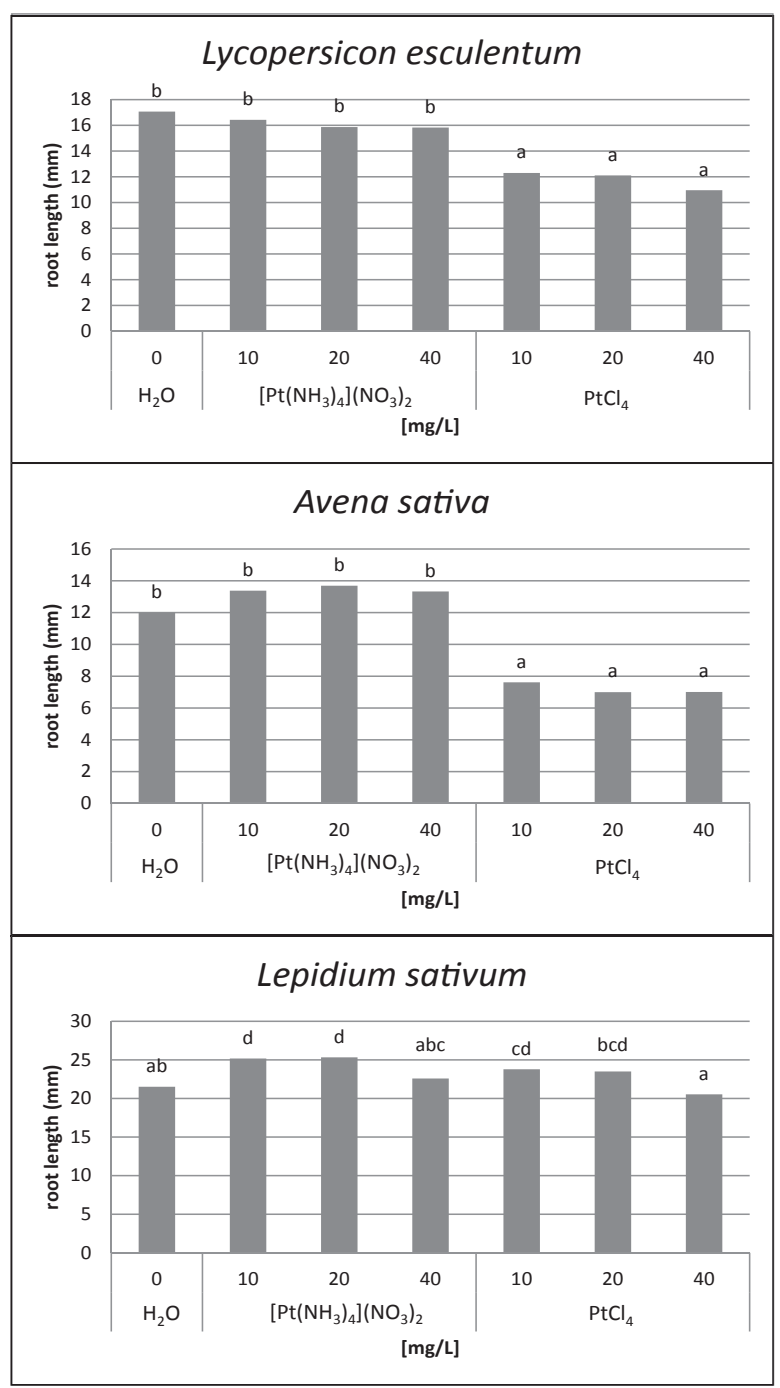

Fig. 2. Root length $(\mathrm{mm})$ of the three plant species affected by platinum ions - experiment $2^{\text {nd }}$. Letters indicate homogenous groups separated with $\alpha=0.05$ 
The root growth of tomato seedlings was not influenced by $\left[\mathrm{Pt}\left(\mathrm{NH}_{3}\right)_{4}\right]\left(\mathrm{NO}_{3}\right)_{2}$. Root growth of oat seedlings was similar in all treatments during the first experiment. Stimulation of root growth was observed in garden cress after incubation in $\mathrm{PtCl}_{4} 1-10 \mathrm{mg} / \mathrm{L}$ solution as compared to control samples. Roots of garden cress was not affected by $\left[\mathrm{Pt}\left(\mathrm{NH}_{3}\right)_{4}\right]\left(\mathrm{NO}_{3}\right)_{2}$.

A greater variability of root growth was observed in the second experiment (Fig. 2). Tomato seedlings incubated in solution of $\mathrm{PtCl}_{4}$ were shorter than control ones and also these incubated in $\left[\mathrm{Pt}\left(\mathrm{NH}_{3}\right)_{4}\right]\left(\mathrm{NO}_{3}\right)_{2}$. The solution of $\mathrm{PtCl}_{4}$ also inhibited the growth of oat roots and, similarly like for the tomato, the $\left[\mathrm{Pt}\left(\mathrm{NH}_{3}\right)_{4}\right]\left(\mathrm{NO}_{3}\right)_{2}$ solution did not affect root growth. It is interesting that in the case of garden cress different responses of plants root growth were observed. Platinum at +2 oxidation state in $\left[\mathrm{Pt}\left(\mathrm{NH}_{3}\right)_{4}\right]\left(\mathrm{NO}_{3}\right)_{2}$ at 10 and $20 \mathrm{mg} / \mathrm{L}$ concentration increased the root growth as compared to control plants. The concentration of $40 \mathrm{mg} / \mathrm{L}$ of $\left[\mathrm{Pt}\left(\mathrm{NH}_{3}\right)_{4}\right]\left(\mathrm{NO}_{3}\right)_{2}$ did not change root length of the garden cress. Only incubation in $10 \mathrm{mg} / \mathrm{L}$ of $\mathrm{PtCl}_{4}$ stimulated the root growth of garden cress. Treating with mixtures of higher concentration of $\mathrm{PtCl}_{4}$ did not affect root length in comparison to control ones.

\section{DISCUSSION}

Plant susceptibility to stress factors depends on growth phase. It is assumed, that seeds germination and seedling growth phases are the most sensitive to unfavorable conditions. That is the reason why seed germination and seedling growth rates are commonly used for toxicity tests (Salavtore et al. 2008, Solanaki \& Dhankar 2011). In the presented study instead of commercially used Phytotoxkit test, influence of solutions containing platinum ions on seed germination and further growth were evaluated. One of the used species was a garden cress (Lepidium sativum) commonly used in toxicity tests (Czerniawska-Kusza et al. 2006). Additionally, the oat (Avena sativa) was chosen which is also used in biological tests (Forester et al. 2009). The third chosen specie was tomato (Lycopersicon esculentum) which is not only a popular vegetable plant but is also used to estimate different solutions toxicity (Salvatore et al. 2008). Lepidium sativum was the least sensitive to different pollutants than other plant species (Czerniawska-Kusza et al. 2006). In the mentioned study, Authors observed that pollution affect in various way the growth of Lepidium sativum: from inhibition to stimulation. Similarly in the presented studies, the garden cress showed no reaction or even growth stimulation under potentially toxic doses of platinum.

In the environment the concentration of platinum is rising. Eckhard and co-workers (2000) observed 4-fold increase of PGE in soil during 2 years of study in Germany. Having this in mind and also results presented by Leśniewska et al. (2004b) and Bednarova et al. (2014) we used quite high concentration of platinum ions in presented experiment.

The salts may limit seed germination and seedling growth multidirectionally. High concentrations of salts may on one hand hinder water uptake, while on the other hand can easily penetrate into the plant. The accumulation of adverse component may result in different toxic symptoms of the test plants, such as the limited growth of the organs.

The study of Li et al. (2005) has shown that Arabidopsis is more sensitive in the growth stage than germination stage to adverse environmental factors such as the concentration of heavy metals $(\mathrm{Hg}, \mathrm{Pb}, \mathrm{Cu}, \mathrm{Zn})$. Higher growth than germination inhibition was observed in the cited study. Similarly, in the presented experiments, there was no effect of platinum ions on seed germination, but the marked effects of the tested solutions on root growth of seedlings was observed. Both inhibition and stimulation of root growth was noticed.

Both tested forms of platinum (both substances) are available for plants (Verstraete et al. 1998, Sobrova et al. 2012). But toxicity of both substances may differ because of the oxidation state of platinum and additional anion (Bae et al. 2014). Despite the fact that $\mathrm{Pt}^{4+}$ is considered to be less toxic to plants than $\mathrm{Pt}^{2+}$ (Sobrova et al. 2012) in the presented study the inhibitory effect on root growth was demonstrated in the case of $\mathrm{Pt}^{4+}$ instead of $\mathrm{Pt}^{2+}$. This effect may be associated with an anion which was introduced through salt dissolution. Chlorine from $\mathrm{PtCl}_{2}$ may be more toxic to plants than nitrate and ammonium ions.

Study was supported by Polish Ministry of Science and Higher Education DS 3500/2014. 


\section{REFERENCES}

Aydinalp C. \& Marinova S., 2009. The effects of heavy metals on seed germination and plant growth on Alfalfa plant (Medicago sativa). Bulgarian Journal of Agricultural Science, 15, 4, 347-350.

Bae J., Mercier G., Watson A.K. \& Benoit D.L., 2014. Seed germination test for heavy metal phytotoxicity assessment. Canadian Journal of Plant Science, 94, 1519-1521.

Bednarova I., Mikulaskova H., Havelkova B., Strakova L., Beklova M., Sochor J., Hynek D., Adam V. \& Kizek R., 2014. Study of the influence of platinum, palladium and rhodium on duckweed (Lemna minor). Neuroendocrinology Letters, 35, 2, 35-42.

Czerniawska-Kusza I., Ciesielczuk T., Kusza G. \& Cichoń A., 2006. Comparison of the Phytotoxkit Microbiotest and Chemical Variables for Toxicity Evaluation of Sediments. Environmental Toxicology, 21, 4, 367-72.

Djingova R., Kovacheva P., Wagner G. \& Markert B., 2003. Distribution of platinum group elements and other traffic related elements among different plants along some highways in Germany. The Science of the Total Environment, 308, 235-246.

Dubiella-Jackowska A., Polkowska Ż. \& Namieśnik J., 2007. Platinum group elements: a challenge for environment al analytics. Polish Journal of Environmental Study, 16, 3, 329-345.

Eckhard J.D., Schäfer J., Puchelt H. \& Stüben D. 2000. Environmental PGE contamination in Southwest Germany. [in:] Zereini F. \& Alt F. (eds), Anthropogenic Platinum Group Element Emissions Their Impact on Man and Environment, Springer-Verlag, Berlin, Heidelberg, New York, 47-55.

Farago M.A., Mullen W.A. \& Payne J.B., 1979. The uptake of platinum group metals by tomato, bean and corn. Inorganica Chimica Acta, 34, 151-154.

Foerster B., Firla C. \& Junker T., 2009. Plant Tests. [in:] Moser H. \& Römbke J. (eds), Ecotoxicological Characterization of Waste, Springer Science+Business Media, 117-118.

Ghani A., 2010. Toxic Effects of Heavy Metals on Plant Growth and Metal Accumulation in Maize (Zea mays L.). Iranian Journal of Toxicology, 3, 3, 325-334.

Hofman M. \& Wachowski L., 2010. Badania zawartości platyny i ołowiu w glebie wzdłuż głównych dróg wylotowych z Poznania. Ochrona Środowiska, 32, 3, 43-47.

Leśniewska B.A., Godlewska-Żyłkiewicz B., Bocca B., Caimi S., Caroli S. \& Hulanicki A., 2004a. Platinum, palladium and rhodium content in road dust, tunnel dust and common grass in Białystok area (Poland): a pilot study. Science of the Total Environment, 321, 93-104.

Leśniewska B.A., Messerschmidt J., Jakubowski N.\& Hulanicki A., 2004b. Bioaccumulation of platinum group elements and characterization of their species in Lolium multiflorum by size-exclusion chromatography coupled with ICP-MS. Science of the Total Environment, 322, 95-108.
Li W., Khan M.A., Yamaguchi S. \& Kamiya Y., 2005. Effects of heavy metals on seed germination and early seedling growth of Arabidopsis thaliana. Plant growth regulation, 46, 45-50.

Ma R., Caroli S., Alimonti A., Petrucci F., Bocca B., Schramel P., Zischka M., Mikulaskova H., Nemcova B. \& Beklova M., 2013. Study of platinum group metals effects on lettuce plants (Lactuca sativa). Abstracts of the 49th Congress of the European Societies of Toxicology (EUROTOX), Toxicology Letters, 221, Supplement, 113.

Moldovan M., Palacios M.A., Gómez M.M., Morrison G., Rauch S., McLeod C., Palacios M.A., Gómez M., Moldovan M. \& Gómez B., 2000. Assessment of environmental contamination risk by $\mathrm{Pt}, \mathrm{Rh}$ and $\mathrm{Pd}$ from automobile catalyst. Microchemical Journal, 67, 105-113.

Pallas J.E. Jr. \& Jones J.B Jr., 1978. Platinum uptake by horticultural crops. Plant and Soil, 50, 1-3, 207-212.

Pawlak J., Łodyga-Chruścinńska E. \& Chrustowicz J., 2014. Fate of platinum metals in the environment. Journal of Trace Elements in Medicine and Biology, 28, 247-254.

Pettersson C., Wass U., Luna M., Saenz J.C. \& Santamaría J., 2002. Environmental risk of particulate and soluble platinum group elements released from gasoline and diesel engine catalytic converters. The Science of the Total Environment, 296, 199-208.

Ravindra K., Bencs L. \& Van Grieken R., 2004. Platinum group elements in the environment and their health risk. The Science of the Total Environment, 318, 1-43.

Salvatore M.D., Carafa A.M. \& Carratù G., 2008. Assessment of heavy metals phytotoxicity using seed germination and root elongation tests: A comparison of two growth substrates. Chemosphere, 73, 1461-1464.

Sethy S.K. \& Ghosh S., 2013. Effect of heavy metals on germination of seeds. Journal of Natural Science, Biology and Medicine, 4, 2, 272-275.

Sobrova P., Zehnalek J., Adam V., Beklova M. \& Kizek R., 2012. The effects on soil/water/plant/animal systems by platinum group elements. Central European Journal of Chemistry, 10, 5, 1369-1382.

Solanki R. \& Dhankar R., 2011. Biochemical changes and adaptive strategies of plants under heavy metal stress. Biologia, 66, 2, 195-2-4.

Supalkova V., Beklova M., Baloun J., Singer C., Sures B., Adam V., Huska D., Pikula J., Rauscherova L., Havel L., Zehnalek J. \& Kizek R., 2008. Affecting of aquatic vascular plant Lemna minor by cisplatin revealed by voltammetry. Bioelectrochemistry, 72, 1, 59-65.

Verstraete D., Riondato J., Vercauteren J., Vanhaecke F., Moens L., Dams R. \& Verloo M., 1998. Determination of the uptake of $\left[\mathrm{Pt}\left(\mathrm{NH}_{3}\right)_{4}\right]\left(\mathrm{NO}_{3}\right)_{2}$ by grass cultivated on a sandy loam soil and by cucumber plants, grown hydroponically. The Science of the Total Environment, 218, 153-160.

Whiteley J.D. \& Murray F., 2003. Anthropogenic platinum group elements (Pt, $\mathrm{Pd}$ and $\mathrm{Rh}$ ) concentrations in road dusts and roadside soils from Perth, Western Australia. The Science of the Total Environment, 317, 121-135. 